\title{
Pendidikan Tinggi di Masa dan Pasca Covid-19
}

\author{
Franciscus Dwikotjo Sri Sumantyo
}

\author{
Fakultas Ekonomi dan Bisnsi; Universitas Bhayangkara Jakarta Raya; Jl. Raya \\ Perjuangan, Marga Mulya, Bekasi Utara, Jawa Barat 17121. Telp: 021-88955882, \\ 889955883; e-mail: franciscus@dsn.ubharajaya.ac.id
}

Korespondensi: e-mail: franciscus@dsn.ubharajaya.ac.id

\begin{abstract}
Beginning at the end of 2019 in various countries around the world and in Indonesia during the period of February 2020 has been shocked by a spectacular outbreak of a virus called Corona or Covid-19 (Corona Virus Diseases-19). This virus originally existed and developed in Wuhan China and its transmission spread very quickly throughout the world. So that the World Health Organization (WHO)(Jianxi Luo, 2020a), declared a world pandemic. Many victims fell and died, including in Indonesia and disrupt human life plus the unavailability of drugs or antidotes for this virus. All sectors in the world experience tremendous impact and ultimately jointly overcome in various ways so that transmission can be minimized, including in the field of education, especially higher education in Indonesia, many efforts have been made in the conditions and situations of teaching in the period and post-pandemic Covid-19. Government efforts in mobilizing and launching an independent campus and WFH-SFH (Nadiem Anwar Makarim, 2020a) are efforts to reduce and overcome Covid-19 servicing on campus and places of education whose potential is extraordinary, if contracting and other efforts undertaken to solve and explained in this study by each - higher education is an effort to minimize and reduce the impact caused by the Covid-19 pandemic.
\end{abstract}

Keywords: Covid-19, pandemic, e-learning, independent campus, Study From Home (SFH)

\begin{abstract}
Abstrak
Berawal akhir tahun 2019 di berbagai negara di belahan dunia dan di Indonesia dari bulan Pebruari 2020 telah dikejutkan oleh wabah spektakuler yaitu virus yang bernama Corona atau Covid-19 (Corona Virus Diseases-19). Virus ini awalnya ada dan berkembang di Wuhan China dan penularannya sangat cepat menyebar ke seluruh dunia. Sehingga oleh World Health Organization (WHO) (Jianxi Luo, 2020a), menyatakan pandemi dunia. Korban banyak berjatuhan dan meninggal dunia termasuk di Indonesia dan mengganggu kehidupan manusia ditambah belum tersedianya obat atau penangkal virus ini. Semua sektor di dunia mengalami dampak yang luar biasa dan pada akhirnya bersama-sama mengatasi dengan berbagai cara agar penularannya bisa diminimalisir, termasuk dalam bidang pendidikan, khususnya pendidikan tinggi di Indonesia telah banyak dilakukan upaya dalam kondisi dan situasi pengajaran di masa dan pasca pandemi Covid-19. Upaya pemerintah dalam menggerakkan dan mencanangkan kampus merdeka dan WFH-SFH (Nadiem Anwar Makarim, 2020a) adalah upaya untuk mengurangi dan mengatasi penyebaran Covid-19 di dalam kampus dan tempat pendidikan yang potensinya sangat luar biasa jika tertular dan upaya-upaya lain yang dilakukan untuk penanggulangannya dan dijelaskan dalam studi ini oleh masing-masing pendidikan tinggi adalah upaya dalam meminimalisir dan mengurangi dampak yang terjadi akibat pandemi Covid19 ini.
\end{abstract}

Kata Kunci: Covid-19, pandemi, pembelajaran online, kampus merdeka, belajar dari rumah

\section{Pendahuluan}

Pada masa akhir-akhir ini berbagai negara di dunia telah dikejutkan dengan wabah spektakuler yaitu wabah penyakit yang disebabkan oleh virus yang bernama corona atau lebih Avaılabıe Unıne at nttp: / / ejurnaı.ubnarajaya.ac.ıa/ Inaex.pnp/ JKI 
dikenal dengan istilah covid-19 (Corona Virus Diseases-19)(Jianxi Luo, 2020b). Virus ini awalnya ada dan mulai berkembang di Wuhan China. Wabah virus ini penularannya sangat cepat menyebar ke berbagai negara sehingga World Health Organization (WHO), menyatakan sebagai pandemi dunia (Kemeskes RI, n.d.).

Penyebaran virus Covid-19 menjadi penyebab angka kematian yang paling tinggi di berbagai Negara di dunia saat ini. Sudah banyak korban yang meninggal dunia termasuk di Indonesia. Bahkan banyak juga tenaga medis yang menjadi korban dan meninggal. Hal ini menjadi perhatian dan permasalahan besar yang harus dihadapi oleh seluruh dunia saat ini, sehingga semua negara melakukan berbagai kebijakan penanggulangannya termasuk di Indonesia. Indonesia juga merasakan luar biasa dampak penyebaran virus ini. Semakin hari semakin cepat menyebar ke sejumlah wilayah di Indonesia dan korban selalu bertambah, baik terpapar dan meninggal. Data per 29 Mei 2020 adalah Total Kasus yang terjadi di Indonesia sebanyak 25.216 pasien positif virus Covid-19, 252 orang pasien dinyatakan sembuh dan total pasien yang sembuh tercatat 6.429 orang pasien. Sedangkan pasien meninggal dunia bertambah sebanyak 24 orang, sehingga total menjadi 1.520 orang kasus kematian.(Tim Detikcom - detikNews, 2020) Dari data hari ini masih memprihatinkan dan perlu antisipasi dan penanganan lebih lanjut secara struktural dan masif (Tim Detikcom - detikNews, 2020).

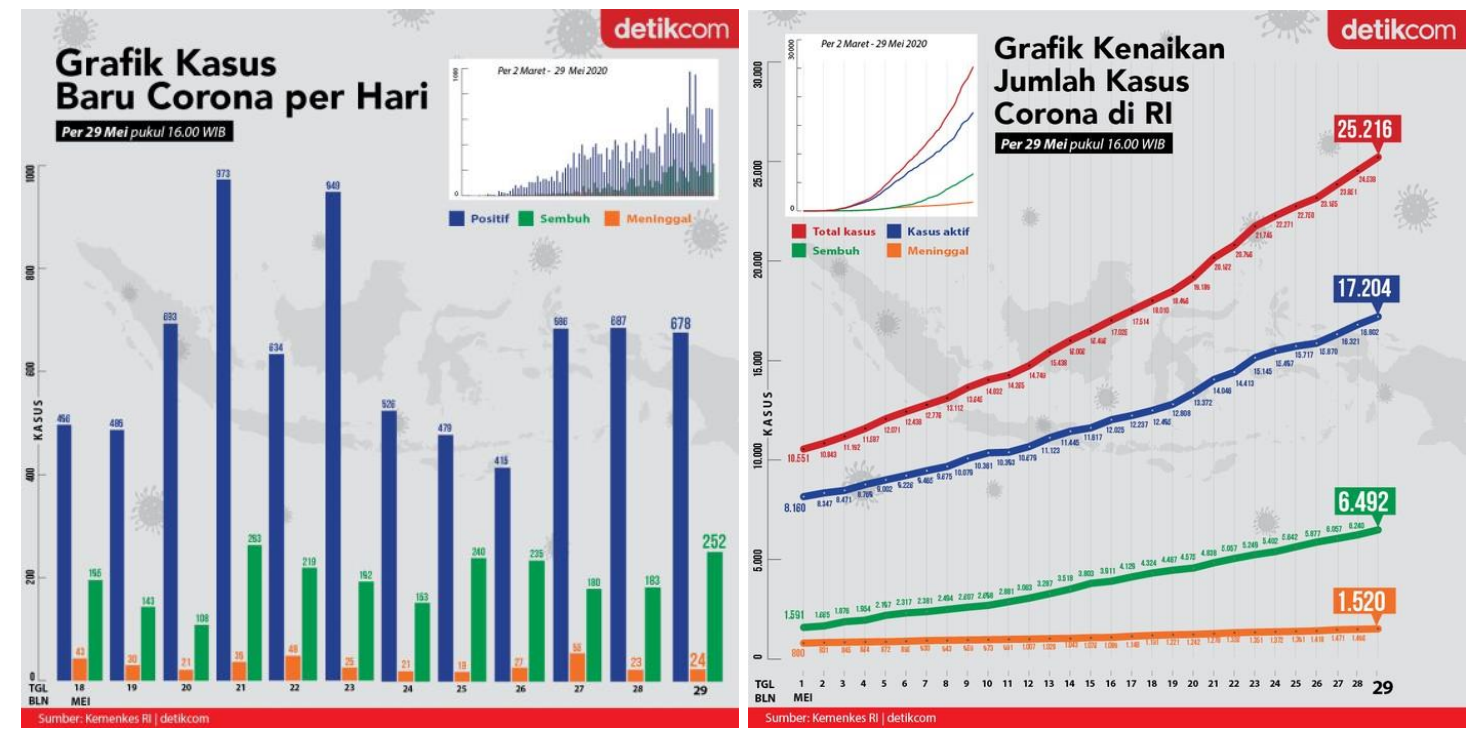

Sumber: (Tim Infografis Detikcom)(Tim Detikcom - detikNews, 2020) (Grafik Corona di Indonesia 29 Mei 2020)

Gambar 1. Kasus Baru Corona per Hari

Gambar 2. Kenaikan Jumlah Kasus Corona di RI

Dilihat dari kurva Corona hari ini pada Gambar 1 dan Gambar 2, kasus sembuh Corona naik ke angka 252 kasus. Kemarin angka kesembuhan mencapai 183 kasus. Sebelumnya 23 orang meninggal karena Corona dan hari ini kematian bertambah 24 orang (Tim Detikcom detikNews, 2020). Kesimpulannya bahwa virus ini masih aktif memakan korban di dunia dan khususnya di Indonesia sehingga perlu penanganan dan antisipasi lebih lanjut agar tidak memakan korban lebih banyak lagi. 


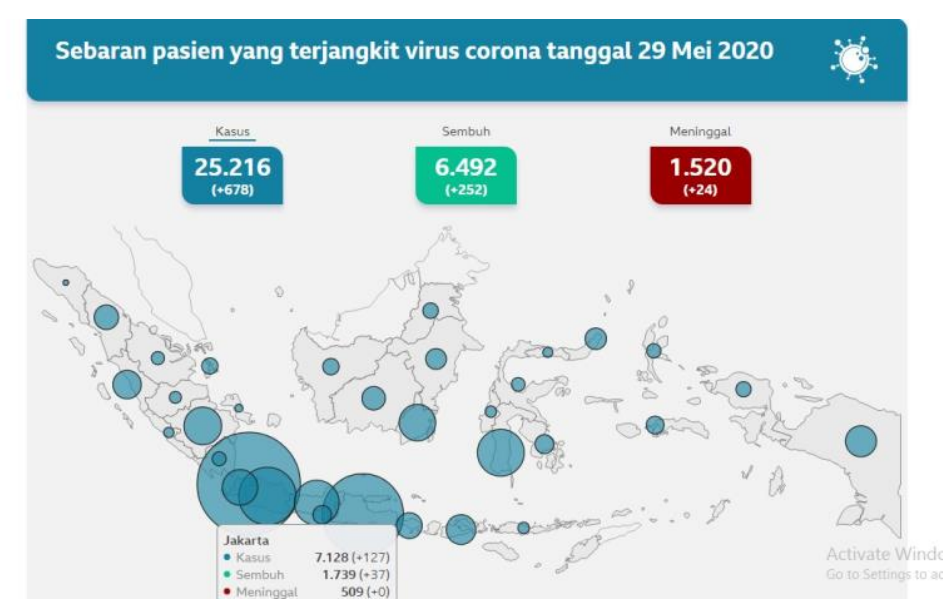

Sumber: Kementerian Kesehatan. Terakhir diperbaharui pada 29 Mei 202016.00 WIB.(Kemeskes RI, n.d.)

Gambar 3. Peta Sebaran Pasien Terjangkit Covid-19 (29 Mei2020)

Selanjutnya dari hasil penelitian para ahli, kapan pandemi Covid-19 ini akan berakhir? Ini menjadi pertanyaan penting seluruh dunia, khususnya di Indonesia. Sehubungan dengan pengaruh seluruh kehidupan manusia, termasuk bidang Pendidikan dan Pendidikan Tinggi khususnya (Kemeskes RI, n.d.). Sehingga ada pertanyaan: Kapan dimulainya pendidikan di Indonesia? Dimana dilaksanakan pengajaran tatap muka dengan para mahasiswa di kampus-kampus yang ada. Sampai saat ini penyebaran dan pasien meninggal masih tinggi sehingga perlu antisipasi agar dengan perkuliahan yang ada tidak menjadi penyebab bertambahnya pasien Covid-19 ini khususnya munculnya cluster baru di kampus-kampus di Indonesia. Sebagai informasi penelitian dari Singapura yang terbaru dari Data Driven Innovation Laboratorium Singapore University of Technology and Design (2020)(Jianxi Luo, 2020a) membuat pola estimasi tanggal berakhirnya kasus penyebaran virus covid19 di setiap negara dunia. Dan sebagai gambaran untuk situasi Indonesia adalah:

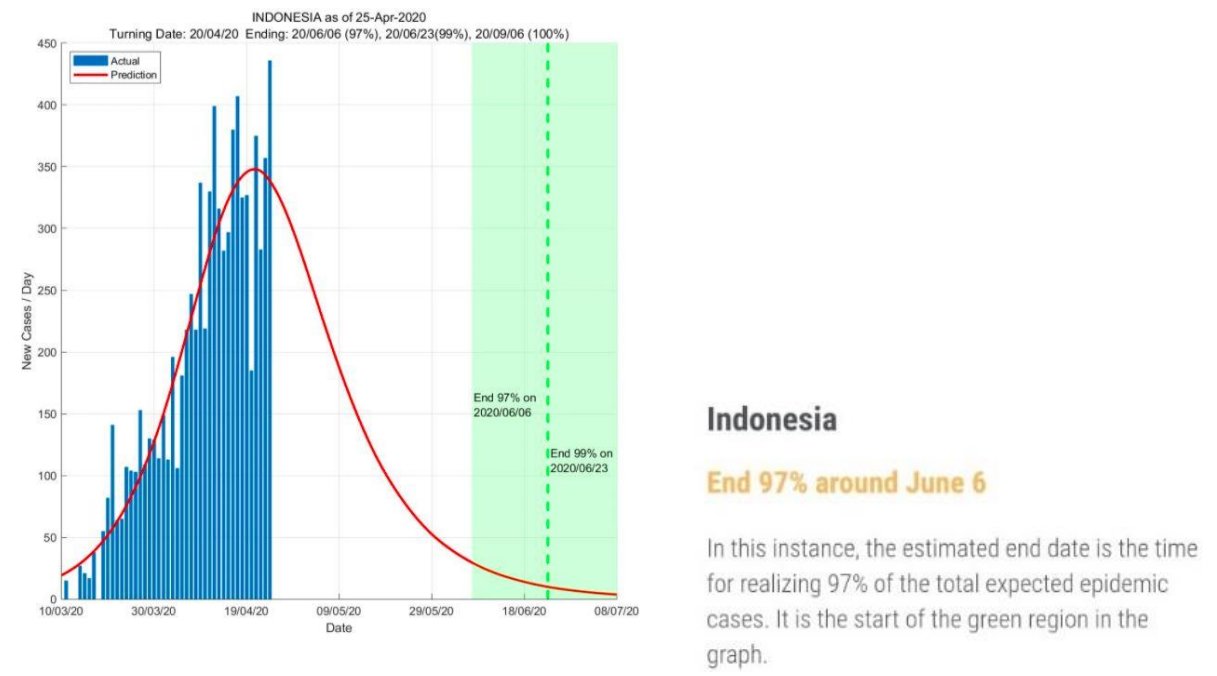

Sumber : Data Driven Innovation Laboratorium Singapore University of Technology and Design (2020) (Jianxi Luo, 2020b)

Gambar 4. Siklus berkurangnya wabah pandemi Covid-19 (Jianxi Luo, 2020b) 
Hasil analisa Indonesia akan mengalami penghentian kasus sebaran Covid-19 sebanyak 97\% pada 6 Juni 2020. Sedangkan kondisi benar-benar aman dari penyebaran Covid-19 ini adalah 8 Juli 2020(Jianxi Luo, 2020a). Hasil penelitian diatas didasarkan atas penerapan sungguh-sungguh protokol Covid-19 dengan kondisi ketat aturan oleh seluruh komponen masyarakat di Indonesia.

Hal ini juga dipengaruhi juga oleh penelitian pembuatan serum penangkal (antibodi) dan penyembuh virus Covid-19 ini yang diprediksi 4 (empat) tahun baru akan dikeluarkan obat untuk obat Covid-19 ini di dunia. Tetapi para ahli farmasi berusaha sekeras mungkin dalam 2 (dua) tahun untuk segera menemukan hal ini agar wabah ini bisa segera ditumpas dan pasien bisa disembuhkan. Berarti masih ada 2 tahun sampai obat corona ini ditemukan dan dipakai sebagai penyembuh penderita karena covid-19. Untuk itu satu-satunya jalan menanggulangi adalah dengan melaksanakan Protokol Covid-19 yang telah ditentukan di setiap bidang kehidupan manusia di dunia ini.

Dengan dasar diatas, maka selanjutnya perlu dilakukan langkah-langkah guna mencegah dan menghindari penyebaran virus Covid-19 yang tengah merebak dibeberapa di dunia, termasuk di Indonesia dan pada dunia pendidikan khususnya.

\section{Metode Penelitian}

Dengan demikian kajian ini merupakan sebuah conceptual-paper terkait perkembangan media informasi dan perilaku masyarakat Indonesia dalam menyikapi pandemi Covid-19 ini melalui temuan data-data informasi dan fakta-fakta yang berasal dari data primer dan sekunder yang berasal dari instansi terkait serta informasi serta data-data yang berasal dari publikasi resmi pemerintah. Tulisan ini diharapkan dapat menjadi sebuah referensi bagi pengamat yang memantau dan perkembangan menuju New Normal dari siklus pandemi yang terjadi khususnya di Indonesia terutama New Normal di bidang pendidikan.

\section{Hasil dan Pembahasan}

Lalu bagaimana dalam dunia pendidikan di Indonesia, tidak semua dosen dan mahasiswa siap dan mampu mengoperasikan teknologi sistem pembelajaran online dengan baik dan cepat, termasuk juga mempersiapkan bahan perkuliahan secara digital.

Terlepas dari ketidaksiapan atau kegagapan bidang teknologi, ternyata ada hal lain yang menjadi masalah adalah kurangnya sarana dan prasarana pendukung yang dimiliki oleh setiap pihak. Banyak dosen dan juga mahasiswa tidak bisa memenuhi fasilitas teknologi ini, jangankan untuk memenuhi bagian ini, bahkan untuk memenuhi kebutuhan hidup sehari-hari juga masih kesulitan. Dan masalah ini, kerap dirasakan oleh masyarakat kita yang berada di perekonomian dari menengah hingga bawah. Sebagai contoh, adanya kuliah daring mengharuskan mahasiswa memiliki laptop dan juga handphone. Namun masih ada di daerah mahasiswa yang tidak memiliki laptop tetapi memiliki handphone, maka mahasiswa yang tidak memiliki laptop akan kesulitan dan warung internet di berbagai daerah saat ini pasti tutup akibat adanya kebijakan PSSB, tidak hanya merasakan kesulitan, mungkin saja mahasiswa tersebut 
bisa berhenti kuliah atau sekolah. Masalah lain yang ikut menjadi dampak pembelajaran online ini adalah jaringan internet dan biaya data internet untuk online (e-learning).

Menurut Dr Gerald (Albertus Adit, 2020) menjelaskan bawah pandemi corona ini diprediksi masih belangsung lama di semua kampus. Menurutnya, prediksi banyak pakar kesehatan, kemungkinan karena vaksin pada umumnya membutuhkan minimal 4 tahun untuk ditemukan, bahkan virus HIV sampai hari ini sejak ditemukan pada tahun 1980, juga masih belum ditemukan vaksinnya. Mahasiswa harus siap mengikuti pembelajaran daring.sebagai tuntutan perkembangan zaman seperti Revolusi Industri 4.0. Banyak ahli yang memprediksi pembelajaran online akan terus berjalan paling cepat akhir 2021 dan kampus akan tutup minimal Maret/April 2021. (Albertus Adit, 2020)

Selanjutnya pembahasan mengenai hal-hal yang berhubungan dengan kondisi dan situasi pengajaran dan pendidikan dalam masa dan pasca pandemi Covid-19 ini:

\section{1) Kebijakan dan langkah strategis kampus menghadapi pandemi Covid-19}

Semua perguruan tinggi di Indonesia dan bahkan dunia pasti mengalami dampak dari Covid-19 ini dan selanjutnya pasti sudah mempunyai planning matang untuk menghadapi tahun ajaran baru 2020/2021. Namun, tentunya rencana yang akan diambil perguruan tinggi harus berbelok tajam dari situasi sebelumnya. Seperti rencana tahapan proses akreditasi, rencana KKN dan Pengabdian Masyarakat, rencana penerimaan mahasiswa baru (Maba), rencana UTS/UAS, rencana proses pengajaran online/e-learning, dll., sehingga kebiasaan yang ada sebelumnya semua menjadi tertunda dan tidak optimal.

\section{Hal-hal yang bisa dilaksanakan kampus adalah}

a. Pelaksanaan Kuliah dan Ujian secara Online/Streaming/e-learning:

Perkuliahan kampus harus tetap dijalankan dalam rangka mengantisipasi penularan dan kontak fisik dengan kuliah jarak jauh dan tidak boleh ketinggalan lagi tentu kebijakan tentang proses belajar mengajar, kebijakan yang bisa diambil seperti: 1) Kuliah online dengan Platform (E-learning, GoogleMeet, Siakad, Zoom, WA), 2) Meminimalisir tugas, 3) Mengutamakan kuliah dan diskusi, 4) UTS/UAS dan Tugas: Online/e-learning dan Take Home b. Menjaga kesehatan dan keselamatan Mahasiswa.

Berdasarkan Data Pemerintah mengenai situasi dan kondisi di Indonesia penyebaran Covid-19 semakin merajalela (Tim Detikcom - detikNews, 2020), keselamatan dan kesehatan mahasiswa tetap harus diutamakan. Berikut kebijakan-kebijakan yang dapat dilakukan untuk keselamatan mahasiswa, seperti: 1) Pelaksanaan kuliah secara online/streaming/e-learning, 2) Pembuatan satgas COVID-19 di kampus, 3) Penetapan Prosedur Protokol Kesehatan Covid-19 di Asrama Mahasiswa atau tempat kost, 4) Prosedur atau Program "Tidak Pulang kampung untuk mahasiswa/tidak mudik"

c. Menjaga kesehatan dan keselamatan Dosen dan Karyawan Kampus.

Selain mahasiswa, keselamatan dan kesehatan dosen dan para pegawai menjadi prioritas. Berikut kebijakan yang bisa dilaksanakan adalah: 1) Pelaksanaan pengajaran atau kuliah secara online/streaming/e-learning yang diakses dari rumah, 2) Pembentukan Satgas COVID-19 di kampus bagi yang masuk kerja atau piket, 3) Penetapan Prosedur Kesehatan 
Protokol Covid-19 di kampus, 4) Prosedur atau Program "Tidak Pulang kampung untuk dosen dan karyawan kampus/tidak mudik", 5) Kerja dan belajar dari rumah (WFH dan SFH) (Albertus Adit, 2020), 6) Prosedur protokol Covid-19 ketika masuk, di dalam dan keluar kampus, 7) Satgas Covid-19 memantau kondisi kesehatan dosen dan karyawan

d. Memodifikasi Program KKN, Praktek dan Magang.

Strategi selanjutnya yang bisa diterapkan kampus untuk solusi KKN. Kerja Praktek dan Magang adalah sebagai berikut: 1) Seluruh Praktikum di Lab yang ada ditunda/ditiadakan, 2) Pengembangan program pengganti PKL dan magang, bisa digantikan dengan kegiatan: Relawan Medis Cofid-19, membantu Tim Medis di Puskesmas, RS, dll.

e. Memodifikasi pelaksanaan Tugas Akhir (TA) dan Sidang.

Strategi selanjutnya yang bisa diterapkan kampus untuk solusi tugas akhir dan sidang adalah sebagai berikut: 1) Seluruhnya konsultasi dan sidang dilakukan secara Online atau Video streaming/video conference/dll. 2) Pengembangan program pengganti Tugas Akhir dengan PKL dan magang dalam masa yang lebih panjang dari Kerja Praktek. 3) Modifikasi tugas akhir dengan praktek langsung membantu penanganan Covid-19.

f. Membantu keringanan biaya kuliah atau kelonggaran waktu pembayaran semester Mahasiswa.

Hal ini bisa dilakukan Kampus untuk membantu mahasiswa agar tetap bisa kuliah karena kondisi ekonomi yang tidak mendukung dengan cara: a) Memberikan keringanan Uang Semester Kuliah, b) Tempo pembayaran diperlunak dengan tenggang membayar dimundurkan atau dicicil.

g. Kesiapan "New Normal" bidang pendidikan.

Kampus harus siap sewaktu-waktu mempersiapkan infrastrukturnya kembali, jika sewaktuwaktu kampus dibuka kembali dengan prosedur protokol Covid-19. Tentunya ada waktu dan tenaga tambahan serta biaya tambahan dikeluarkan dalam rangka untuk mengantisipasi penularan Covid-19 di dalam kampus.

\section{2) Kegiatan pembelajaran dan implementasi di masa pandemi}

Kementerian Pendidikan dan Kebudayaan (Kemendikbud) mengeluarkan kebijakan baru diberi nama "Merdeka Belajar, Kampus Merdeka" (Nadiem Anwar Makarim, 2020b). Kebijakan ini dimaksudkan menggali potensi terbesar para guru-guru sekolah dan murid kita untuk berinovasi dan meningkatkan kualitas pembelajaran secara mandiri agar pihak kampus lebih leluasa bergerak, lepas dari belenggu yang selama ini dihadapi dengan mencanangkan reformasi sistem pendidikan Indonesia melalui kebijakan Merdeka Belajar (Nadiem Anwar Makarim, 2020b). Konsep Merdeka Belajar tersebut bisa membuat guru dan dosen fokus mengembangkan potensi siswa dan terhindar dari berbagai tekanan yang menghambat proses belajar. Hal lain yang positif bahwa konsep ini bisa memunculkan potensi pengajar yang memang berbakat dan siap dengan kondisi dan media apapun. Akhirnya muncul kendala karena tikungan terjal dunia pendidikan saat pencanangan Merdeka Belajar akhirnya terhambat pandemi mewabah dan menghambat sistem belakang mengajar di dunia. 
Program tersebut bahkan dipuji bagus jika memang bisa terlaksana. Hanya saja, realitanya tidak semua sekolah di seluruh Indonesia siap melaksanakan. Terutama sekolah di daerah yang masih memiliki keterbatasan guru dan sarana pra sarana di kota dan daerah, apalagi daerah terpencil. Konsep Kampus Merdeka dari kebijakan dan penerapannya revolusioner. Merefleksikan gagasan purba yang diinisiasi Bapak Pendidikan Indonesia Ki Hajar Dewantara. Tentang kebebasan pelajar atau mahasiswa dalam menuntut ilmu sesuai dengan bidang yang ingin ditekuninya. Antara lain, kegiatan magang di industri atau organisasi, kegiatan pertukaran mahasiswa ke kampus lain, kegiatan proyek di desa atau pelosok daerah, kegiatan proyek kemanusiaan, kegiatan kewirausahaan, penelitian, studi independen, atau kegiatan mengajar di desa. (Nadiem Anwar Makarim, 2020a)

Ada 4 kebijakan terkait paket Kampus Merdeka ini, yaitu (Nadiem Anwar Makarim, 2020a): 1) Kemudahan dalam membuka program studi baru, 2) Akreditasi Perguruan tinggi, 3) Perubahan status menjadi Perguruan Tinggi Negeri Badan Hukum, dan, 4) Belajar di perguruan tinggi (hak belajar tiga semester di luar program studi).

Merdeka Belajar (Nadiem Anwar Makarim, 2020b) dimaksudkan untuk memberikan kebebasan kepada mahasiswa untuk memilih bidang sesuai yang mereka butuhkan sehingga tercipta kultur belajar yang inovatif, tidak mengekang dan sesuai dengan kebutuhan mahasiswa. Artinya, mahasiswa tidak hanya unggul dari bidang akademis melainkan juga terampil dari bidang keterampilan yang diperlukan pasar. Caranya adalah dengan menambah porsi vokasional melalui blended kurikulum akademik-vocational.

Tabel 1. Implementasi Merdeka Belajar

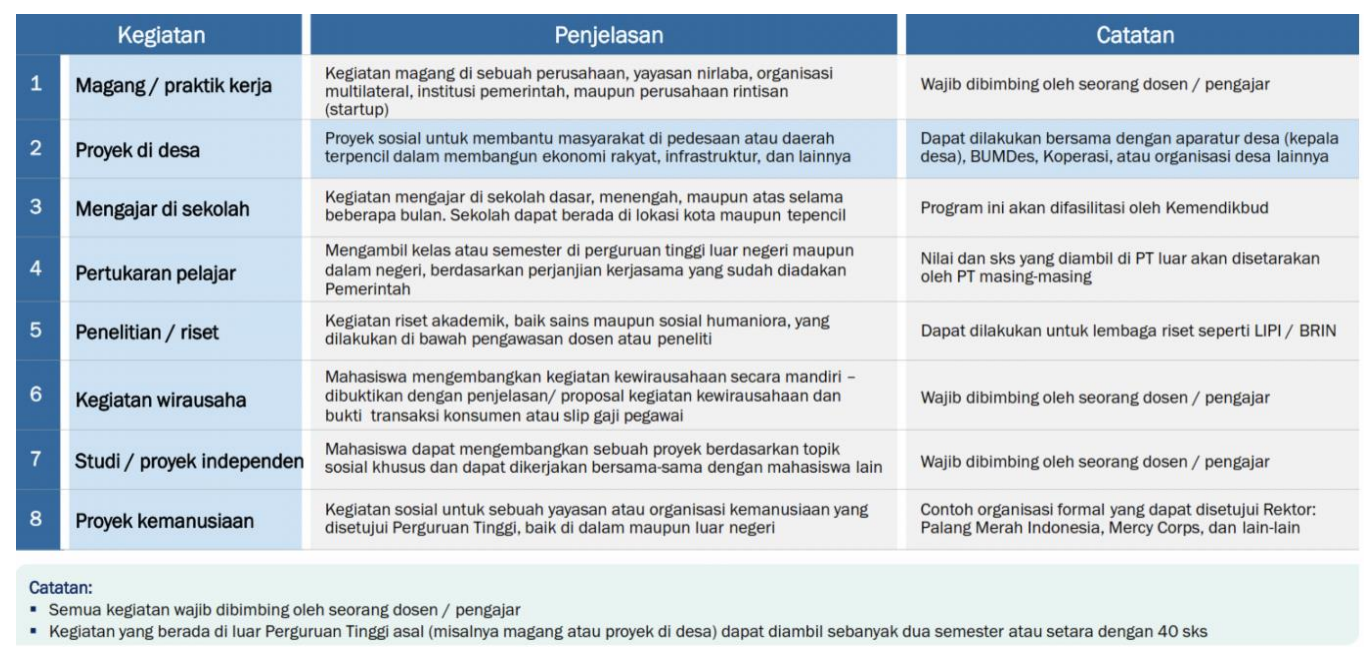

Sumber : Kementerian Pendidikan RI (2020) (Nadiem Anwar Makarim, 2020b)

Sudah siapkah kampus untuk menerapkan metode baru ini Kampus Merdeka?

Setiap kebijakan baru membawa konsekwensi baik terkait dengan infrastruktur pendukung maupun mindset para pelaksananya. Ada baiknya dengan Merdeka Belajar program studi yang selama ini tidak melaksanakan kegiatan KKN dengan alasan ada mata kuliah magang/praktik industry selanjutnya dapat memasukkan mata kuliah tersebut ke dalam kurikulum, tanpa menghilangkan kegiatan magang dari kurikulum.

Seiiring dengan perubahan metode diatas, tentunya tambahan beban biaya bagi mahasiswa apalagi kondisi pandemi Cofid-19 ini, semuanya menjadi kendala besar 
pembiayaan program baru di pendidikan. Walaupun dengan kata belajar merdeka, ternyata tetap saja ada kendala lapangan yang tak terduga sehingga pelaksanaan program pun bisa tidak berjalan dengan baik dan lancar.

Sebagai usulan dan masukan demi baiknya bahwa program merdeka belajar atau kampus merdeka ini tidak bisa dilaksanakan tahun ini mengingat pengaruh pendemi Covid-19 dan faktor penghambat lain adalah penyiapan infrastruktur dan program belum maksimal dan biaya yang penjadi kendala utama di masa pandemi Covid-19 karena banyak mahasiswa dan orangtua menjadi korban masa PSBB Pandemi Covid-19 ini. Tentunya program ini akan berjalan baik dan lancar di Tahun 2021 seiring wabah Covid-19 sudah berlalu dan perekonomian bangsa sudah dapat berjalan lancar dan kehidupan mulai bangkit kembali sehingga kemampuan daya beli dan nafkah hidup mulai kembali normal. Selanjutnya dunia pendidikan akan kembali normal dan program-program pendidikan dapat dilaksanakan sesuai rencana.

\section{3) Terobosan riset dan inovasi yang dihasilkan}

Beberapa penelitian riset yang dapat dilakukan perguruan tinggi untuk menghadapi Covid-19 yang bersifat tepat guna, tetap sasaran dan langsung terapan, antara lain: a) Penemuan zat penangkal, antibodi dan serum untuk melawan Covid-19, b) Pola hidup dan perilaku cara sosialisasi masyarakat yang berbeda, c) Rancang bangun RS darurat, d) Ide kreasi model pakaian anti virus Covid-19, e) Teknologi Face shield, f) Pengembangan APD dan Masker, g) Hand Sanitizer, h) Model baru Public Sanitized Hand Wash, i) Pengembangan Teknologi Filter Udara, j) Pengembangan Teknologi Respirator dan Ventilator, k) Pembuatan Database Besar IT Covid-19 untuk analisa lanjut, I) Metode pembelajaran jarak jauh / elearning, m) Penemuan-penemuan kreasi baru bidang medis, misalkan: alat pacu jantung, respirator, dll, n) Bidang Manajemen memberikan semangat pada para penjual atau produsen UMKM dalam memberikan motivasi, masukan, bimbingan usaha dan mendorong untuk semangat berkarya dan berusaha untuk siap menghadapi bisnis yang sedang lesu dan membantu usaha tetap jalan dengan media online dan media komunikasi WA, Instagram, FB, dll.

\section{4) Pengabdian masyarakat, bergotong royong mengatasi masalah Covid-19 :}

Seiring dengan pola hidup dan pola pengajaran yang berubah, maka pola pengabdian masyarakatpun yang dilakukan Universitas pada bidang pengabdian masyarakat pun harus berubah mengikuti situasi dan kondisi yang ada sekarang karena Covid-19 ini.

\section{Kegiatan yang dapat dilakukan diantaranya adalah}

a. Menjadi sukarelawan medis Tim Covid-19 sebagai pengganti KKN selama masa tertentu.

b. Membantu Tim medis dalam sosialisasi antisipasi dan menangani masyarakat yang terpapar Covid-19 untuk terus menjaga kesehatan dan tetap tinggal di rumah. Turut menggemakan kampanye Covid-19 kepada masyarakat.

c. Membantu pemerintah dalam mendistribusikan bantuan sosial pemerintah yang terdampak Covid-19 ini, bisa disinergikan dengan Program KKN. 
d. Kegiatan sosial menggalang dana kemanusiaan untuk membantu perekonomian masyarakat miskin, tersinggir dan disabilitas di wilayah sekitar kampus. Kegiatan sosial bisa dilaksanakan universitas dalam membantu masyarakat yang terdampak ekonomi selama masa pandemi Covid-19 ini.
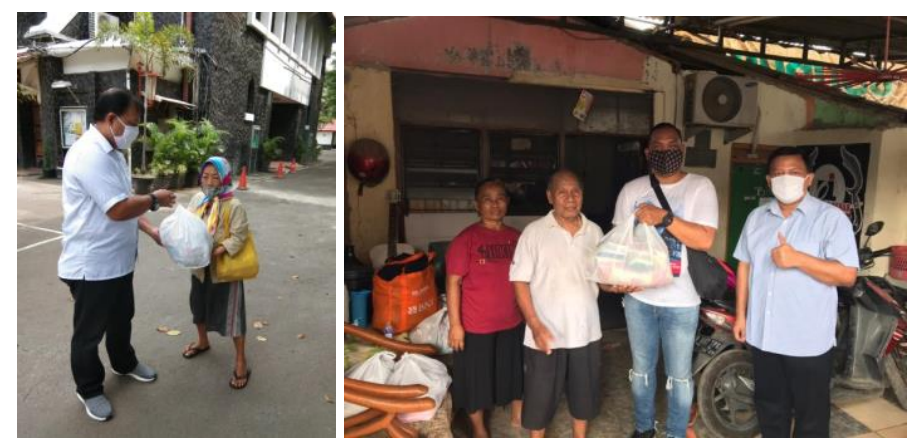

Gambar 5. Baksos bagi yang terdampak ekonomi karena Covid-19

e. Kegiatan sosial dalam membantu pemenuhan peralatan pendukung medis bagi RS dan masyarakat yang membutuhkan di saat peralatan medis langka dan mahal di pasaran, misalkan: masker, APD, tameng pelindung muka, vitamin, desinfektan, dll.

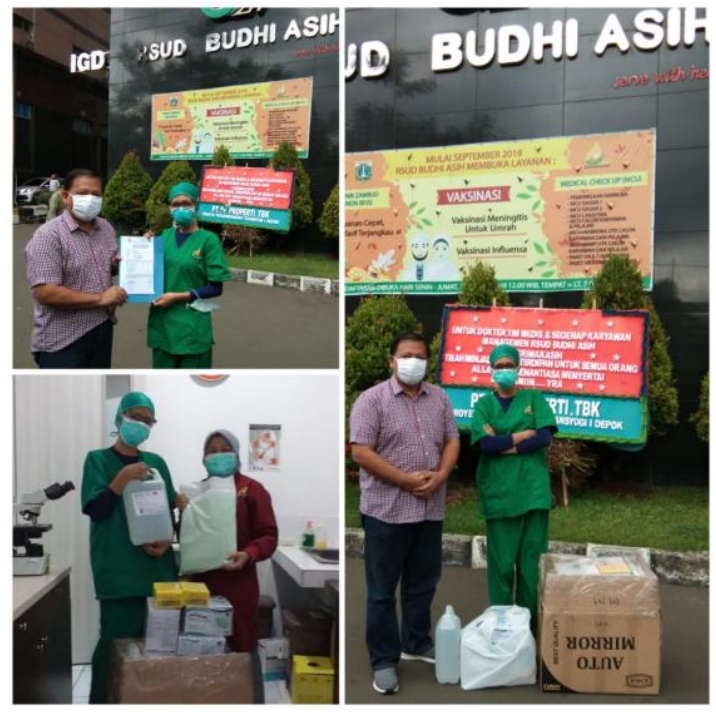

Gambar 6. Memberikan bantuan kepada RSUD Budi Asih Jaktim berupa: 100 buah APD \& nurse caps, Masker, handsanitizer, vitamin, dll

f. Kegiatan pendampingan masyarakat dalam pengembangan ekonomi kreatif dalam bidang pangan dan kebutuhan sehari-hari masyarakat, agar masyarakat bisa tetap bisa hidup dengan penghasilan dari menjual barang, makanan atau produk yang bisa dijual secara online (e-commerce).

g. Pembinaan UMKM sekitar kampus dengan membina cara produksi dan pendanaan agar UMKN bisa tetap bertahan hidup di masa sulit karena pandemi Covid-19 ini.

h. Peningkatan keyakinan dan pendampingan sosial masyarakat yang terdampak tekanan mental batin masyarakat karena dampak Covid-19 melalui usaha dan kegiatan bidang rohani, psikologi dan sosial kemasyarakatan agar masyarakat tetap semangat hidup dalam menghadapi situasi sulit saat ini. 
i. Mengelola dapur umum untuk masyarakat terkena musibah, miskin, tersingkir dan tersisih dalam mambantu makanan selama masa Covid-19 ini.

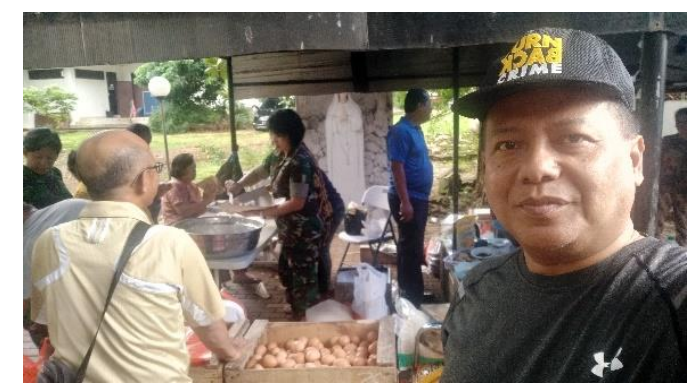

Gambar 7. Dapur Umum untuk masyarakat yg terdampak eko-nomi karena Covid-19

j. Peran lain Kampus dalam pembinaan rohani kepada masyarakat sekitar kampus dapat bekerjasama dengan para tokoh agama atau FKUB Kab/Kota/Prov setempat dalam memberikan pelayanan rohani dan penguatan iman kepada masyarakat yang terdampak Covid-19.

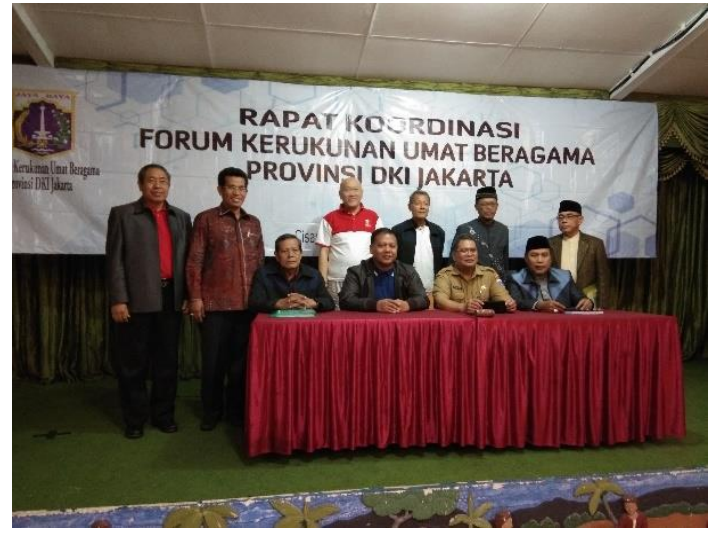

Gambar 8. Peran FKUB dalam rangka membantu masyarakat di tengah pandemi Covid-19 (2020)

\section{5) Pembelajaran yang diperoleh dan harapan ke depan:}

Pembelajaran yang diperoleh: Tidak ada suatu usaha yang tidak ada manfaat dan hasil, walaupun gagal tetap memberi manfaat dan pengajaran yang berharga untuk lebih maju ke depan dengan pengalaman yang ada untuk mencapai kesempurnaan. Pengalaman Covid19 diatas membawa musibah secara global, tetapi dapat diambil manfaat dari bidang yang lain.

Seperti bidang pendidikan dapat diambil manfaat, diantaranya: a) Penguasaan teknologi informasi semakin lebih baik terutama untuk belajar jarak jauh (e-learning) yang selama ini masih menjadi keraguaan tingkat keefektifannya. Dengan masa pandemi ini kita "dilatih paksa" untuk belajar secara daring walaupun masih banyak kekurangan disana-sini yang akhirnya bisa kita atasi bersama. b). Menjadi prioritas dalam pengembangan dan peningkatan kemampuan teknologi informasi pendidikan di kampus karena semakin diperhatikan dan manjadi prioritas dalam pemakaiannya sehingga perlu terus dikaji dan dikembangkan sesuai kebutuhan masing-masing Universitas dalam mendukung proses belajar 
mengajar secara daring ini, c) Berlomba-lomba para ahli dalam riset penemuan vaksin Covid-19 sehingga dunia pendidikan dan riset berperan penting dalam usaha menemukan vaksin baru ini.

Harapan kedepan: a) Sebagai akibat pandemi Covid-19 di Indonesia ini diterapkannya kebijakan dalam memutus rantai penyebaran virus covid-19. Upaya pemerintah menghimbau kepada masyarakat agar melakukan physical-distancing yaitu menjaga jarak aman diantara masyarakat, menjauhi aktivitas dalam segala bentuk kerumunan dan menghindari adanya pertemuan yang melibatkan banyak orang dilakukan untuk memutus rantai penyebaran virus covid-19 yang terjadi saat ini. Sehinga untuk bidang Pendidikan Tinggi sebaiknya protokol ini tetap dijalankan sebagai syarat utama. Dan keyakinan untuk itu di dalam kampus masih diragukan karena berkumpul dan bersosialisasi sangat tinggi dan penularan semakin mudah dan cepat, maka sebaiknya pengajaran secara tatap muka tidak dilaksanakan dahulu sampai kondisi benar-benar wabah ini mereda dan menghilang. Sehingga tetap pengajaran dilaksanakan secara daring sampai situasi benar-benar aman dan wabah bisa diatasi bersama. Kepekaan Pemerintah dalam menerapkan kebijakan yaitu Work From Home (WFH) dan Study From Home (SFH) (Albertus Adit, 2020) ini merupakan upaya yang diterapkan kepada masyarakat luas agar dapat menyelesaikan segala pekerjaan dari rumah. Dengan adanya pembatasan interaksi, Kementerian Pendidikan di Indonesia juga mengeluarkan kebijakan yaitu belajar dari rumah (Nadiem Anwar Makarim, 2020a), dengan meliburkan sekolah dan mengganti proses Kegiatan Belajar Mengajar (KBM) dengan menggunakan sistem informasi dengan jaringan internet (daring). Kebijakan Pemerintah ini berharap tetap dilaksanakan sampai benar-benar wabah Covid-19 berakhir yang diperkirakan masih berlangsung sampai akhir tahun di bulan 7 Oktober 2020 (Peneliti SUTD Singapore).(Jianxi Luo, 2020b), b) Pengembangan dan peningkatan kemampuan teknologi informasi pendidikan ini terus dikaji dan dikembangkan sesuai kebutuhan masing-masing Universitas, sehingga proses belajar mengajar secara daring menjadi lebih baik dan tidak membosankan dan media komunikasi pengajaran tetap bisa dijaga konsistensinya., c) Belajar mandiri lebih dikedepankan sehingga mahasiswa harus semakin kerja keras belajar, sehingga membina dan membantu mahasiswa utk meningkatkan kemampuan dan jam belajar secara mandiri.

\section{Kesimpuan}

Pada akhirnya walaupun pendidikan di Indonesia ikut terdampak adanya pandemi covid-19 ini, namun dibalik semua itu terdapat hikmah dan pelajaran yang dapat diambil dalam proses pendidikan di Indonesia serta upaya untuk mencerdaskan bangsa adalah tetap berjalan dengan baik dan harapan kemajuan bangsa melalui pendidikan tetap menjadi prioritas pemerintah RI dalam mengemban tanggung jawab bangsa dan negara. Bekerja dari rumah (WFH) dan Belajar dari rumah (LFH), tidak berkumpul dan menjaga jarak adalah dianggap cara yang terbaik untuk memutus mata rantai penyebaran virus Covid-19 ini khususnya di bidang pendidikan. Penutupan sementara lembaga pendidikan adalah sebagai upaya menahan laju penyebaran virus covid-19 di seluruh dunia yang berdampak pada jutaan pelajar dan 
mahasiswa, termasuk di Indonesia yang berdampak pada psikologis anak didik dan menurunnya kualitas keterampilan dan daya pikir mahasiswa. Beban itu merupakan tanggung jawab semua elemen pendidikan, khususnya negara dalam memfasilitasi kelangsungan kampus atau sekolah bagi semua pemangku pendidikan guna melakukan pembelajaran jarak jauh.

\section{Ucapan Terima Kasih}

Disampaikan kepada Tim Gugus Tugas Percepatan Penanganan Covid-19 Pemprov DKI Jakarta dan Tim Gugus Tugas Covid-19 Pemerintah Kota Administrasi Jakarta Timur yang telah memberikan data, informasi, bekerja sama tugas di lapangan, diskusi dan memberikan kontribusi dalam penulisan ini.

\section{Daftar Pustaka}

Albertus Adit. (2020). Ini Poin Penting Persiapan Kuliah di Masa Pandemi Corona Artikel ini telah tayang di Kompas.com dengan judul "Ini Poin Penting Persiapan Kuliah di Masa Pandemi Corona", httplni-poin-penting-persiapan-kuliah-di-masa-pandemi-corona. Kompas.Com. https://www.kompas.com/tag/persiapan-kuliah

Jianxi Luo. (2020a). Predictive Monitoring of COVID-19. In Data-Driven Innovation Lab Singapore University of Technology and Design. https://people.sutd.edu.sg/jianxi_luo/public_html/COVID19PredictionPaper.pdf

Jianxi Luo. (2020b). When Will COVID-19 End? Data-Driven Prediction. https://www.flasog.org/static/COVID-19/COVID19PredictionPaper20200426.pdf

Kemeskes RI. (n.d.). Situasi Terkini Perkembangan Coronavirus Disease (Covid-19), 29 Mei 2020. https://covid19.kemkes.go.id/situasi-infeksi-emerging/info-corona-virus/situasiterkini-perkembangan-coronavirus-disease-covid-19-29-mei-2020/\#.XybfhpYzblU

Nadiem Anwar Makarim. (2020a). Mendikbud Luncurkan Empat Kebijakan Merdeka Belajar: Kampus Merdeka. https://www.kemdikbud.go.id/main/blog/2020/01/mendikbud-luncurkanempat-kebijakan-merdeka-belajar-kampus-merdeka

Nadiem Anwar Makarim. (2020b). Merdeka Belajar: Kampus Merdeka. Kemedikbud RI. https://www.kemdikbud.go.id/main/blog/2020/01/kebijakan-merdeka-belajar--kampusmerdeka

Tim Detikcom - detikNews. (2020). Grafik Corona RI 29 Mei: Kasus Baru Turun, Angka Kesembuhan Naik. Tim Detikcom - DetikNews. https://news.detik.com/berita/d5033832/grafik-corona-ri-29-mei-kasus-baru-turun-angka-kesembuhan-naik 